\title{
Insurgency in Nigeria: The Perspectives on Health Care Delivery to Gender Affected Victims amongst IDPs
}

\author{
Hindatu Maigari Yerima ${ }^{1}$ D.S. Ranjit Singh ${ }^{1}$ \\ ImajiZekeriOjonumiache Sule ${ }^{I}$ School of International StudiesUniversiti Utara Malaysia
}

\begin{abstract}
The Boko Haram (BH) emerged in Nigeria in 2002 with the aim of total implementation of the Sharia law in Nigeria, yet there are other reasons such as socio-economic factors in the north-east where the group has been more prevalent. The domestic-based insurgent group became more sophisticated after its establishment of links with some international terrorist organizations (ITOs) such as Al-Qaeda, AQIM and AlShabaab. The group made its attacks to threaten the national security of Nigeria in the destruction of lives, properties and displacement of people and genders such as women and children. These displaced people have no option than to live in camps with serious need of social amenities such as health care. These camps are mostly provided, supervised and catered for by state governments and joint efforts of local international donors. This paper seeks to argue that the activities of Boko Haram led to destruction of properties, killing of people and also made most of them to become internally displaced without some essential needs in their camps, particularly health care for the women. To attain these objectives of this paper, a qualitative research method was adopted through which data were collected through documentary analysis. This study discovered thatwhile the government and some non-governmental institutions claimed to have provided some health care services for the gender victims in the camps, some of the victims debunked the claim. The paper therefore recommended that government and other non-governmental organizations should come to aid of the victims particularly the gender with health care services and other necessary needs for those internally displaced persons as a result of the effects of the activities of BH insurgent group.
\end{abstract}

Keywords: Boko Haram, Insurgency, Health care delivery and National Security

\section{INTRODUCTION}

Boko Haram that emerged in 2002 as a domestic based insurgent group became more popular after its clash with the security agencies in 2009 that led to the killing of its leader Muhammad Yusuf in an extra-judicial manner after which the group became more sophisticated; radically more violent and determined; a change that can be argued to be as a result of its establishment of links with international terrorist organizations. The changes induced by international terrorist organizations brought about new methods of violence which include that of suicide bombings, kidnappings, killing of police at check points which have not been the insurgent's earlier methods due to its domestic nature.Boko Haram has the plan of making Nigeria to adhere to Islamic Sharia law, but its activities became possible due to the deterioration socio-economic situation prevailing in the North-east part of Nigeria where the group is more prevalent. As earlier posited above, the link of the insurgent group with international groups such as Al-Shabaab and AQIM brought about the high profile level of attacks by Boko Haram insurgents in 2011 which amounted to the bombing of the police headquarters in Abuja, and two months later the attack against the United Nations (UN) headquarters took place in Abuja, the Federal Capital of Nigeria which led to the death of 23 people and about 81 others injured (BBC, 2011).

Since 2009 arising from the attacks of the group, Nigeria national security became threatened to the extent that over 2,000 Nigerians were killed in more than 100 attacks by Boko Haram. This act by the group also led to displacement of gender related victims such as women, girls and children who necessarily deserve some social amenities and particularly, health care services delivery. The groups to brutality increase by January 2012, it carried out its first most deadly single day attack in Kano with about 185 people killed. This attack brought about declaration of state of emergency by the Nigerian government in the states of Borno, Yobe and Adamawa in May 2013 (Blanchard, 2014).The North-Eastern region has the highest number of IDPs totaling 11,360 as a result of being the centre of the insurgent group. Most of the men are killed during the attacks; therefore the women and children end up in the IDPs without any protection (Ladan, 2013). Therefore these women and children below 18 years of age constitute the higher percentage. According to Joseph (2016) "surveyresults indicate that out of 20738 IDP households included, 51.8\% of the IDPs are female while $48.2 \%$ aremale. The results further indicate that $55.7 \%$ of the IDPs are children below 18 years, and more than halfof them are within 05 years age bracket". They become vulnerable to all sorts of vices. The camps are haphazardly put together with no basic amenities to cater for the number of people living there. 
The most disturbing aspect accompanied with the changes of the group brought about by its links with the international terrorist organizations as observed above was the growing sophistication and expertise of the sect since 2011 which were noticed in the areas of weaponry and the frequencies of incidences of attacks with improvised explosive devices (IEDs), car bombs, and suicide bombings used in carrying out its attacks (Walker, 2012).In view of the above trend therefore, this paper intends to investigate how the Boko Haram activities in Nigeria affects the gender related victims in the perspective of health care delivery from the angle of the government and other institutions from within and outside the country. The paper also probe into the reality of the health care delivery by the government and other related institutions as viewed by the gender related victims themselves.

\section{LITERATURE REVIEW}

Boko Haram insurgents emerged in 2002, yet other insurgent groups exist earlier before it (Onuaha, 2010). It was further reported that the group originated as a result of some Nigerian students in the University of Maiduguri Nigeria, but couldn't complete their studies and hence decided to align with the Boko Haram group in 2002 (Gusau, 2009).Madike (2011) agreed with the above when he stated that: “The group's first leader was oneLawanAbubakar, an Islamic cleric who later proceeded for further studies at the University of Medina in Saudi Arabia in 2002". After the departure of Lawan for Medina, Chothia informed that another leader took over the leadership from him when he stated that: A Muslim cleric by the name Ustaz Mohammed Yusuf, took over the leadership and later established a religious complex with a mosque and an Islamic boarding school in Maiduguri, Borno state, along with a prayer group which he called "Jama'atulAlhulSunnahLidda'watiwal Jihad" otherwise known in Arabic as "people committed to the propagation of the Prophet's teachings and jihad (Chothia, 2011). To the group their name is as mentioned above by Chothia, but there are opinions that the group is more popularly referred to and better known by a combination of Hausa and Arabic as Boko Haram, meaning "Western education is sinful" (Adesoji, 2009: 100).

Boko Haram which started operation in the year 2002 as a domestic insurgent group metamorphosed in 2010 to an organization with links to international terrorist organizations in its tactics, due to its corroboration with outside terrorist groups such as AQIM and Al-Shabaab which are all affiliates of Al-Qaeda terrorist network (Mantzikos, 2010:1).The Boko Haram Islamic sect declared Maiduguri city in Borno state as an Islamic state that controlled the affairs of the State in the north-east of Nigeria as intolerably corrupt and irredeemable, hence the group embarked on hijra (a withdrawal along the lines of the Prophet Mohammed's withdrawal from Mecca to Medina). The group moved to a village called Kenama, in Yobe state and called on other Muslims to join them in the struggle to return the society to a life under "true Islamic law", with the aim of making a more perfect society different from the corrupt establishment of the moment (Walker, 2012:2).

It may be recalled that from 2002 to 2009 when the group clashed with the police, they were mainly involved in preaching without violence activities hence they were dormant and not well heard of until the incidence mentioned above. The above event made the Bauchi state government to crack down on them with the arrest of more than 700 of its members. In Maiduguri, the police surrounded the group's mosque, but members of the sect managed to break out and for three days later, they were involved in serious breach of security. They roamed the city acting independently, fighting police when they come across them and killing Muslims and Christians indiscriminately. The police eventually regained control of Maiduguri, and embarked on a bloody attack on the group's members and anyone they suspected to be supporter of Boko Haram. Dozens of people were rounded up and executed without trial. Mohammed Yusuf, the group's leader was arrested by the army and handed over to the police, who killed him within hours and claimed that he was shot while trying to escape (Walker, 2012:4). The extra judicial killing of their leader fanned the crisis out of proportion.The activities of the insurgent group made many people homeless and particularly the genders, women and children who have no option but to leave their homes to camps where others affected with the destruction of lives and properties occasioned by Boko Haram referred to as internally displaced persons are kept in camps with little or none availability of social service such as health care delivery. The unprecedented number of people in the camps and improper planning by both Federal and States governments created the environment for nefarious activities within these camps. According to UNFPA report, some of the IDPs women and girls were sexually assaulted. Therefore diseases such as HIV/AIDs, STDs, were spread around the camps. Another problem is that of unwanted pregnancies. Due to the nature of the camps the victims have no any form of protection hence the spread in disease. Hunger also served as motivator for the victims because their molesters offer them food in exchange of sex. There is also no school or any form of academic engagement for the children therefore they become easy targets. Thus, women and children are more vulnerable to the activities of BokoHaram than the men (Joseph,2016). 


\section{METHODOLOGY}

The method of data collection for this paper was that of a qualitative one. Qualitative research is a method of inquiry that in most cases produces results in words rather than statistics (Bello, 2007).

The emphasis on sources of data was historically based on primary documents and analysis of documentary evidences which include government documents and reports; documents from international organizations such as Amnesty International and United Nations; Newspapers and Magazines; and internet was usedfor this paper.

\section{DISCUSSION AND FINDINGS}

In this paper, some findings were arrived at as discussed below:

\subsection{Debate onthe Provisions of Health Care Services for Gender Victims of Boko Haram Insurgents from Government agents and other institutions}

Quoting the National Emergency Management Agency's (NEMA) Displacement Tracking Matrix, the National Population Commission (NPC) has disclosed that over 80 per cent of the country's 2.2 million internally displaced persons (IDPs) resulting from Boko Haram activitiesare women and girls. The commission which bemoaned that women and girls has always been at the receiving end of crisis such as that of Boko Haram added that the recent rescue operations of captives from the Sambisa forest shows that most of them are women and children (Today.news, 2015).

The fact remains that healthcare delivery is equally a fundamental human right issue in Nigeria and globally too. This view is buttressed to the effect that the Economic, Social and Cultural Rights (ESCR) when it state that

The right to health also includes the right to access information concerning health care. It further stressed that the realization of women's right to health care requires the removal of all barriers interfering with access to healthcare services, education and information" (ESCR, Committee No.14, para.12 b). Still on the need for health care for citizens and particularly, genders, the Convention on the Rights of Persons with Disabilities went on to state that government are required to ensure that citizens should be granted access to health care services that are gender sensitive including health-related rehabilitation (CRPD).It is reported that there are not less than 30 pregnant women located among the displaced persons as a result of the activities of Boko Haram insurgents who aretaking refuge at one of the Internally Displaced Persons (IDP's) camps in Maiduguri who have been delivered of their babies. The Chairman of the Committee on the IDP's at the Government Girls Secondary School Maiduguri camp in person of AlhajiBabagana Mahmoud stated that the pregnant women were said to have mostly come from Bama. Mahmoud further added that government has also set up a committee on safe-motherhood in various camps to assist women before, during and after delivery.Still on the role of government on health care delivery by government institutions, the Chairman of the committee on IDPs went on to state that:

There are health workers at the camp who regularly check the health condition of the IDPs because we are aware of the condition and trauma they've undergone before finding their way to Maiduguri.So we provide adequate health services to them and that's why we hardly record any case of complications among them especially during and after delivery particularly for women (Mahmoud, 2014).Furthermore, in the effort to provide health care for gender affected due to Boko Haram insurgents, the government through National Emergency Management Authority (NEMA) Presented maternal kits to pregnant women in various camps of Maiduguri metropolis, the state capital of Borno state. The director of NEMA of the state further stated that "In the 26 IDP camps we have in Maiduguri, more than 60 per cent of the IDPs are women and children who are the vulnerable groupwhich made the government to support the vulnerable as part of its duty to provide care for the less-privileged in the society" (Allafrica, 2015). Below are some of the women with their children in one the internally displaced camps.

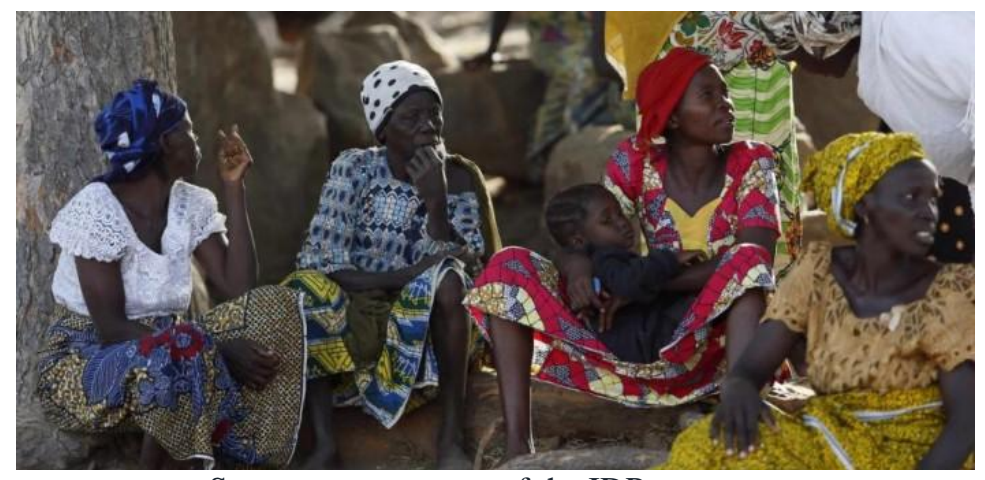

Some women at one of the IDP camps. 
The spokesman of the Adamawa state-run NEMA in person Ezekiel, stated that the agency has been meeting the needs of the displaced people and that "NEMA is on the ground providing the vulnerable with food, shelter and drugs," he said. "Our appeal is for those affected to come to the camps so that we can attend to them. We cannot go to people's homes to give relief to them. They have to come to the camps and the collection centers to receive support," Ezekiel said only eight percent are in the camps while the majorities are staying with their host communities. "For them to be reached, they have to register with NEMA so that we will know exactly those we have to take care of," he added (Ezekiel, 2015).Arising from the increase in the number of women and girls rescued from the Boko Haram insurgents, UNFPA, the United Nations Population Fund, in close collaboration with the Borno State Ministry of Health has decided to step up their support for gender vulnerable in the areas of training of health workers who were subsequently mobilized and deployed within 24 hours to the Internally Displaced Persons (IDPs) camps where they were responsible for the provision of psychosocial support counseling to the traumatized women and girls and make referrals for the most complicated cases among them.

A majority of the rescued girls who were counseled are pregnant which led to the provision of additional reproductive health kits and dignity kits to Borno and Adamawa States for safe delivery to prevent maternal or infant death (UNFPA, 2015).The representative of UNFPA in Nigeria in person of Mrs. Ratidzai buttressing the effort of UNFPA above when she stressed that "Our level of preparedness enabled us to respond almost immediately, we do not select which rescued girl to support but we support all girls, including Chibok girls, because in UNFPA, everyone counts, she continued". Personnel are in place -including a psychosocial support expert trainer- and necessary supplies, including kits, are available to meet the physical, emotional, psychological and medical needs of the women and girls on arrival (ibid).

It was further argued that the humanitarian response program of UNFPA was scaled up in 2014 to cover six States (Yobe, Gombe, Bauchi, Kaduna, Adamawa and Borno) through which 21,800 clean delivery kits and 17,664 female dignity kit has beendistributed. As a result of these supplies, by the end of the year, 16,350 women had safe deliveries in the Fund's supported facilities across the six states. While a total of 73 women with complications received comprehensive care, including caesarian sections, at the supported referral centers. There were no maternal deaths (UNFPA, 2015).

For the purpose of provision of health care for gender vulnerable, about 121 health workers received training on psychosocial support services through which sixty doctors, midwives and nurses were trained on minimum initial service packages for reproductive health in humanitarian settings. Furthermore, 60 health-care providers were trained on clinical management of rape and-post abortion management and 50 midwives and nurses were trained on providing long-acting re-serviceable contraceptives, which enable these vulnerable women to avoid unintended pregnancies (ibid).

Almost 123 cases of sexual violence cases were reported in security posts and 45 cases in health facilities of Adamawa and Borno State. This jump in reporting is associated with increased awareness of genderbased violence resulting from community sensitization sessions carried out in camps. Also, the increased availability of trained health personnel to provide services and of supplies for treatment at the camp clinics have in turn strengthened the health systems for the continuous provision of sexual and reproductive health services in the Northeast.In total, more than 700 traumatized people including the rescued women and girls have received psychosocial support from trained health personnel at UNFPA-supported facilities at the camps for those displaced in Borno State (UNFPA, 2015).

\subsubsection{Perception of the Gender Victims on Health Care Services Delivery to Internally Displaced Persons in Camps}

Despite the efforts of the government and other institutions that claimed to have provided some health care facilities as reported above, there are some arguments against the same report. The National Emergency Management Agency which claimed to have rendered some health care facilities to gender related victims reported that health services have collapsed in states affected by the Boko Haram insurgency in the North-East, NEMA stated that the insurgency had brought the health system to "total collapse" in most local government areas of Borno state in the north-east(Thesunnewspaper,2014) According to the report by NEMA, about 37 per cent of the primary health care centers in most affected local government areas in the north-east have been shut down due to activities of the Boko Haram insurgency.NEMA further reported that the existing health centers were overwhelmed by the number of Internally Displaced Persons (IDPs) who are in need of health care assistance (ibid). It was further stated that in spite of relentless efforts from institutions in charge of health care facilities to attend to IDPs, the need for emergency health support had become enormous. Another area that suffered short comings in the area of health care services for genders affected by the Boko Haram activities is that of Post-trauma and long-term counseling in the areas worst-affected by the assault caused by the insurgents which are greatly needed. Maiduguri's Federal Neuropsychiatric Hospital said between 10and 20 percent of people living in Borno need emergency mental- 
health services (Mahmud, 2014).According to Human Rights Watch (HRW) that interviewed some affected family members, showed some signs of stress and anguish, some of them were said to sometimes stop midsentence to stare in the distance, weeping, and rocking in agitation as they spoke. For instance, a 17-year-old girl repeatedly scrubbed herlegs with open palms while narrating her long trek through the night with her abductors totheir camp. And a 15-year-old girl in her own report said:I could not stop crying even when the insurgents threatened to kill me if Ididn't keep quiet. I kept on thinking, is it not better to die now than to facewhatever terrible things they could do to me when we get to their camp?Even after I escaped from them and live far away from my village, I am stillafraid. I think of death many times. My father tries. He encourages me toforget everything, but it is not easy for me. I have terrible dreams at night (HRW, 2014)According to HRW, on the victims interviewed, only the Chibok students had received some type of statesupportedcounseling and medical care. Borno State government officials told HumanRights Watch that the escaped Chibok students had been provided with post-traumapsychological counseling and medical service (HRW, 2014).

Yet, the young women and girlsinterviewed described the counseling received as religion-based when they informed that the Borno Stategovernment only arranged for pastors and Muslim clerics to speak with about 30 of them ina group at the Governor's office. One girl described the counseling she received thus:

We were all in a big hall, with many people that we did not know. It waswhen one of the speakers quoted from the Bible that I knew he was a pastorbut I cannot remember what he said. As he finished his talk, themicrophone was handed to a man dressed like a Muslim preacher, whoalso recited some Islamic words. Some other people also spoke. No oneasked us any questions. I don't think any of my schoolmates realizedeither that we were being counseled (HRW, 2014).

Still on trauma and stress experienced by victims of the insurgents, A girl who escaped from Boko Haram during the Chibok incident explained the type health assistance that she needs when she stated that "I just want someone who will listen to me and help me to stop the fearthat takes over my mind when I think of my sisters (school mates) who are still with BokoHaram. I am so afraid for them. Why can't the government bring them back?"(HRW, 2014).

Still on lack of health care facilities for victims of Boko Haram insurgent, it was further reported that none of the other victims of abduction or other violated by Boko Haram interviewed by Human RightsWatch had received any government-supported mental health or medical care. Indeed theywere unaware of any government services or programs set up to address theirpsychological or medical needs. Any medical care they received was paid for by their family or church community. For instance, a 19-ooyear-old rape victim quoted above stated thus: "My churchcommunity paid for my physical checkup at the hospital. So at least I know I don't haveany physical damage. They also took my blood but I don't know what they tested it for (HRW, 2014)Among the rape survivors interviewed by Human Rights Watch had no any information abouthow and where to access post-rape care, including treatment for any physical injuries, post-exposure prophylaxis (PEP) to prevent HIV transmission and for sexually transmitteddiseases, and emergency contraception for those who escaped or were released by theircaptors within 72 hours of the rape (ibid).Buttressing the claims of nonavailability of health care for all victims, a public health physician involved in the Borno State government-led initiative to providepsychosocial and medical services to the victims agreed that the program aspresently designed is focused on the Chibok girls, noting that the government does not have any health care for other abductees (HRW, 2014).

Furthermore, the former Borno State commissioner for health admitted that there is a "dearth of mental healthservices" in the state even before the present Boko Haram violence activitiescoupled with the additional challenges caused by the growingnumber of internally displaced persons and the inadequate number of healthcare workers, many of whom had fled their posts in the rural areas for fear of their lives. She said some 40 healthcare workers had recently been trained in counseling, but "because of theinsurgency a lot of them were displaced and we are now left with only four counselors (PSTM, 2014).

\section{CONCLUSION/RECOMMENDATIONS}

On a concluding note, it is argued that Boko Haram's activities serves as threat to National security of Nigeria because, its takes over some territories in the north-east part of the country when the government of a state is meant to protect the integrity, sovereignty, national core values and interests of the state from attacks by any hostile force either from internal or external (Mbachu and Chukwudi 2009:7). Analyzing the concept of security, Buzan, considers security from three levels in his analysis of security paradigm. He discusses "security in relation to specific threats with emphasizes on social threats that are intertwined in human environment with unavoidable social, political and economic consequences" (Buzan, 1983:20). In literary terms, security implies the state of feeling safe and protected, or the assurance that you will not lose something of importance. This simplistic definition implies absence of threat both internal and external to physical survival. In an individual, community or a state, if an individual or nation is under threat from either internal or external forces, a state of insecurity exists. In the presence circumstances, Boko Haram has deprived the communities in some states of 
the north-east part of Nigeria from the above mentioned quality of lives.From the above therefore, it can be seen that the threat to National security in Nigeria by the insurgents calls for serious concern for those who really care for the unity of Nigeria at heart. For now, the country has to count with damaging effect from the sects in attacks and killings of innocent people as well as destruction of public and private properties. Churches and schools are burnt, police stations are set ablaze, and both Christians and Muslims are killed including gender related victims such as women and children, while many of those displaced have no option but leave in camps for the internally displaced persons (IDPs).Due to this adverse situation resulting from the Boko Haram activities women and children that found themselves in the camps were involved with inadequacy of health care delivery as internally displaced persons arising from the ineffectiveness on the part of the government to counter the activities of the Boko Haram insurgency.This paper wish to recommend that the government need to put in motion seriously means of combating the Boko Haram insurgents in Nigeria through series of strategies such as cutting the such of funding for the Boko Haram; prevent the supply of weapons; create jobs for the youths and most importantly adoption of alternative method such as human security such as winning of hearts and minds instead of the use of only military force. On the health care delivery for the gender related victims of the Boko Haram insurgents, government should Provide access to adequate medical and mental health services to victims of abduction and women and girls in the internally displaced camps; develop confidential referral systems and health posts in high-risk areas, such as large or isolated internally displaced persons' (IDP) camps, which can facilitate referrals and access to emergency treatment for women who are victims of sexual violence; ensure that hospitals and clinics treating civilian victims are equipped with medical supplies to treat post-rape care in accordance with World Health Organization (WHO) standards and ensure that all facilities have procedures in place to respond to sexual violence, including Post-exposure Prophylaxis (PEP) kits.On the final note, all services should have trained staff to deliver confidential and comprehensive medical treatment and psychosocial support. If and when services are not available, facilities should have adequate referral systems to ensure that survivors can access confidential care; provide specialized training for healthcare and social service providers to ensure care, treatment, and support to women and child survivors. Training should include both individual and community approaches where needed.

\section{REFERENCES}

[1] Adesoji, A. (20o9). "The Boko Haram Uprising and Islamic Revivalism in Nigeria”, in Africa Spectrum, 45(2): $95-108$

[2] BBC, (2011). Abuja attack: Car bomb hits Nigeria UN building. http://www.bbc.com/news/world-africa14677957

[3] Blanchard, L., 'Nigeria's Boko Haram: Frequently asked questions', Congressional Research Service, May2014, http://fas.org.

[4] Bello, A.B.E (2007), Business research methods, second edition, New York, Oxford university press

[5] Buzan, B. (1983). People, States, and Fear: The National Security in International Relation. Wheatsheaf Books, Michigan.

[6] Chothia, F. (2011) "Who are Nigeria's Boko Haram?" BBC News (2011, August 26).Online at: http://www.bbc.co.uk/news/world-africa-13809501.Retrieved 01/09/2013

[7] Gusau, I. U, (2009, August 2). "Boko Haram: How It All Began, "Daily Trust, Onlineat:http://sundaytrust.com.ng/index.php?option=com_content\&view=article\&id=825:boko-haram how-it-all-began-\&catid=3: peoplein-the-news\&Itemid=110.

[8] Human Rights Watch Report (July 7, 2014) Telephone Interview with Parents of two Chibok Schoolgirls.

[9] Human Rights Watch Report (2014) Telephone Interview with Borno State Government Officials.

[10] Human Rights Watch interview with victim Yola, June 21, 2014.

[11] Human Rights Watch interview with victim Abuja, June 23, 2014

[12] Human Rights Watch Report (June 25, 2014)

[13] Joel, O. A. (2015).Over 410 births in camps for Boko Haram displaced: relief agency. AFP

[14] Joseph Arochi, M. (2016).Internally Displaced Persons and Boko Haram Activities in Nigeria.

[15] Ladan, M. T. (2013). Conflict and its Impact on National Development: With Particular Reference to Northern Nigeria. Available at SSRN 2336163.

[16] Madike, I. (National Mirror, June 9, 2011) "Boko Haram: Rise of a deadly sect," National Mirror Online at: http://nationalmirroronline.net/sunday-mirror/big_read/14548.html; Retrieved on 23/01/2014

[17] Mantzikos, L. (2010). The Absence of a State in Northern Nigeria: The case of Boko Haram African Renaissance Vol. 7 No 1, 57-62.

[18] Mahmoud, B.M (2014) “The Nigerian Insurgency: A Neuroscience Perspective," Sahara Reporters (New York). http://saharareporters.com/2014/04/03/nigerian-insurgency-neuroscience-perspective (accessed November 10, 2015). 
[19] NEMA (2014). Insurgency worsens health care delivery in North-East Nigeria Friday, April 25 , $\underline{2014} 2$ Latest News in Nigeria

[20] NEMA (2015) 80 per cent of Nigeria's $2.2 \mathrm{~m}$ IDPs are women, girls https://www.today.ng/news/national/53405/80-per-cent-of-nigerias-2-2m-idps-are-women-girls-nema

[21] Njadvara, M (2015)NEMA Distributes Delivery, Maternal Kits to Borno IDPs. Allafricahttp://allafrica.com/stories/201508141013.html

[22] Onuoha, F.C. (2011). 'Small Arms and Light Weapons Proliferation and Human Security in Nigeria,'Conflict Trends, 1, pp. 50-56

[23] Ratidzai, N (2015). Boko Haram attacks leave over $2.1 \mathrm{mn}$ displaced in Nigeria

[24] Representative, UNFPA/Nigeria.

[25] Sahara Reporters (New York), June 4, 2014,Inter-Faith Group Counsel Escaped Chibok Girls, Says Governor Shettima, http://saharareporters.com/news-page/inter-faith-group-counsel.

[26] The Sun Newspaper (2014). Timothy, O. Boko Haram: 30 women give birth at IDPs camp in Borno,http://sunnewsonline.com/new/boko-haram-30-women-give-birth-at-idps-camp-in-borno/

[27] Walker, A. (2012)." What is Boko Haram? US Institute of Peace, Special Report. www. USIP. Org. office of the coordinator for counter terrorism, country Report on Terrorism Online at: http://www.youtube.com/ watch 